\title{
Numerical Modelling of Piezoelectric Based Energy Harvesting from The Bridge Structure
}

\author{
Bendine Kouider ${ }^{1}$, Alper Polat ${ }^{2} *$ \\ ${ }^{1}$ University of SidiBel-Abbès, Mechanics of Structures and Solids Laboratory, Department of Mechanics, Faculty of \\ Technology, DjillaliLiabès, Algeria \\ ${ }^{2}$ Munzur University, Civil Engineering Department, Faculty of Engineering, 62100, Tunceli, Turkey \\ kouider84@live.com ${ }^{\mathrm{D}}$, *alperpolat@munzur.edu.tr $\mathrm{iD}$, \\ Received date: 17.09.2020, Accepted date: 16.12.2020
}

\begin{abstract}
Bridges can be subjected to a variety of external loads that can lead to instability and cause vibrations. Fortunately, such vibrations can be a source of unlimited sustainable energy that may powers the devices used to monitor the bridges. A possible way to convert such vibrations is by utilizing the direct piezoelectric effect, a process known as piezoelectric based energy harvesting. The present study investigates piezoelectric energy harvesting from a bridge. A model of the bridge with mounted piezoelectric harvesters was developed under ANSYS APDL. Various scenarios with different moving loads were investigated in time and frequency domains. Moreover, the effect of the positions of the harvesters was also explored. Results confirmed that harvesting vibration energy from bridge systems is a promising source of energy. Also, it can be profitable if the harvesters are located near the maximum mode shape amplitude and they are designed in a way to make their natural frequency match the natural frequency of the moving loads.
\end{abstract}

Keywords: Bridge, energy harvesting, numerical modelling, piezoelectric, vibration

\section{Köprü Yapısından Piezoelektrik Tabanlı Enerji Hasadının Sayısal Modellemesi}

Öz

Köprüler, dengesizlik ve titreşimlere neden olabilecek çeşitli harici yüklere maruz kalabilirler. İyi tarafindan bakıldığında, bu tür titreşimler sınırsız bir enerji kaynağı olabilir ve köprüleri izlemek için kullanılan cihazlara güç sağlayabilirler. Mekanik titreşimler, genellikle piezoelektrik tabanlı enerji hasadı olarak bilinen bir işlem olan doğrudan piezoelektrik etkisinden yararlanılarak elektrik enerjisine dönüştürülür. Bu çalışmada bir köprüdeki piezoelektrik enerji kazanımı incelendi. Piezoelektrik enerji toplayıcıları yerleştirilen köprünün bir modeli ANSYS APDL kullanılarak oluşturuldu. Zaman ve frekans bölgelerinde farklı hareketli yüklere sahip çeşitli senaryolar incelendi. Ayrıca, toplayıcıların pozisyonlarının etkisi de araştırıldı. Elde edilen sonuçlar, köprü sistemlerinden titreşim enerjisinin toplanmasının umut verici bir enerji kaynağı olduğunu gösterdi. Ayrıca toplayıcıların maksimum mod şekil genliğine yakın yerleştirilmesi ve hareketli yüklerin doğal frekanslarının toplayıcıların doğal frekansına uyacak şekilde tasarlanması durumunda daha faydalı olabileceğini gösterdi.

Anahtar Kelimeler: Köprü, enerji hasadı, sayısal modelleme, piezoelektrik, titreşim

\section{INTRODUCTION}

Over the past few decades, wireless sensing technology has been widely adopted for controlling and monitoring bridges (Paek et al., 2005; Lynch and Loh, 2006; Kim et al., 2007). However, for optimal results, it is required that wireless sensors included in the system must continually function during the bridge service. In order to ensure such continuous functionality, a permanent power supply is needed. Among the energy sources for powering the wireless sensors network, self-power energy by harvesting the bridge vibration induced by traveling vehicle and convert it into useable electric power is a promising permanent power sources. Three essential methods that convert ambient energy such the vibration into electric energy have been investigated by the research community, which are electromagnetic induction (Park and Kim, 2016; Torres et al., 2017), electrostatic generation (Boisseau et al., 2012; Basset et al., 2014) and piezoelectric effect (Anton and Sodano, 2007; Ertürk et al., 2009; Lin et al., 2011; Bendine et al., 2017). 
Among the aforementioned methods, the piezoelectric based vibration technique has demonstrated superior ability in converting the energy due to its easy application and high power density.

The literature is based on two main approaches for using piezoelectric devices to harvester traffic induced vibration of the bridge. The first one is realized by embedding the piezoelectric device into the bridge surface. The methods use the direct contact between the vehicle and the piezoelectric patch to generate the electric charge based on the direct effect strain deformation of the piezoelectric material. Several papers have dealt with this approach, for more details on its implementation the reader can refer to (Cahill et al.,2014; Zhang et al.,2016; Jung et al.,2017). The second approach on which the present paper focuses is based on the use of cantilever beam piezoelectric harvester mounted to the bridge as a converting mechanism. The moving vehicle induced dynamic responses of the bridge; these vibrations are transferred to the piezoelectric harvester as a base excitation and then converted into electric power (Ertürk, 2011; Peigney and Siegert, 2013; Zhang et al., 2014). Energy is obtained from the vibration caused by the vehicles passing through the bridges (Karimi et al., 2016). In their study, energy is collected by using console beam type piezoelectric energy harvester. In another study, the optimum dimensioning of the piezoelectric cantilever beam is made under the low frequency condition using the finite element method. ANSYS software is used as the finite element method. Designed by comparing the results of analytical and finite element method (Zhao et al., 2018). Two different piezoelectric harvesters are designed with different frequencies then the vibration created by the vehicles on the bridges. As a result of the study, it is observed that the energy obtained is different even if the energy harvesting machines are placed symmetrically (Zhang et al., 2018). In another study, the energy collected by the piezoelectric energy harvester from the vibration created by the railway bridge is investigated by the finite element method.
Hamilton's variation principle is used in his study (Song, 2018). Vibration energy is collected with a piezoelectric energy harvester placed under the bridge, which is exposed to different movement load types depending on time (Bendine et al., 2019).

In previous studies, the bridges were modeled as a simple beam and geometry complexity was not considered. This can lead to misunderstanding the real behavior of the bridges. The present study provides the research community a well trusted numerical model of real life bridge with piezoelectric harvesters using ANSYS APDL. The model is ableto study the effect of the moving load type and frequencies on the harvested voltage. It is worthy to mention here that the code can be share under request. The following paper is structured as follow:

-Firstly, the bridge with eight harvesters has been modeled and subjected to a harmonic analysis which helps to find the harvesters best positions, then single and double moving loads were applied to the bridge in the time domain which helps estimate the accumulation harvested voltage during the service life of the bridge.

-Finally, the bridge is subjected to random moving loads to simulate the real-life forces acted on the bridge and accordingly check the effect of such loads on the harvested voltage.

\section{MATERIAL AND METHODS \\ Problem Statement}

In this study, a finite element model of a bridge with unimorph piezoelectric is proposed for the energy-based vibration harvesting simulation. The piezoelectric harvesters were mounted to the bottom of the bridge to convert its vibration into electrical power. The idea behind this is that as the traffic moved along the bridge the piezoelectric harvesters would captured the vibrations and converted them into electrical energy. The bridge was designed as a plate on which the traffic loads were considered as moving loads. The harvesters were connected to resistors to measure the electrical energy. The whole structure of the bridge is given in Figure 1. 


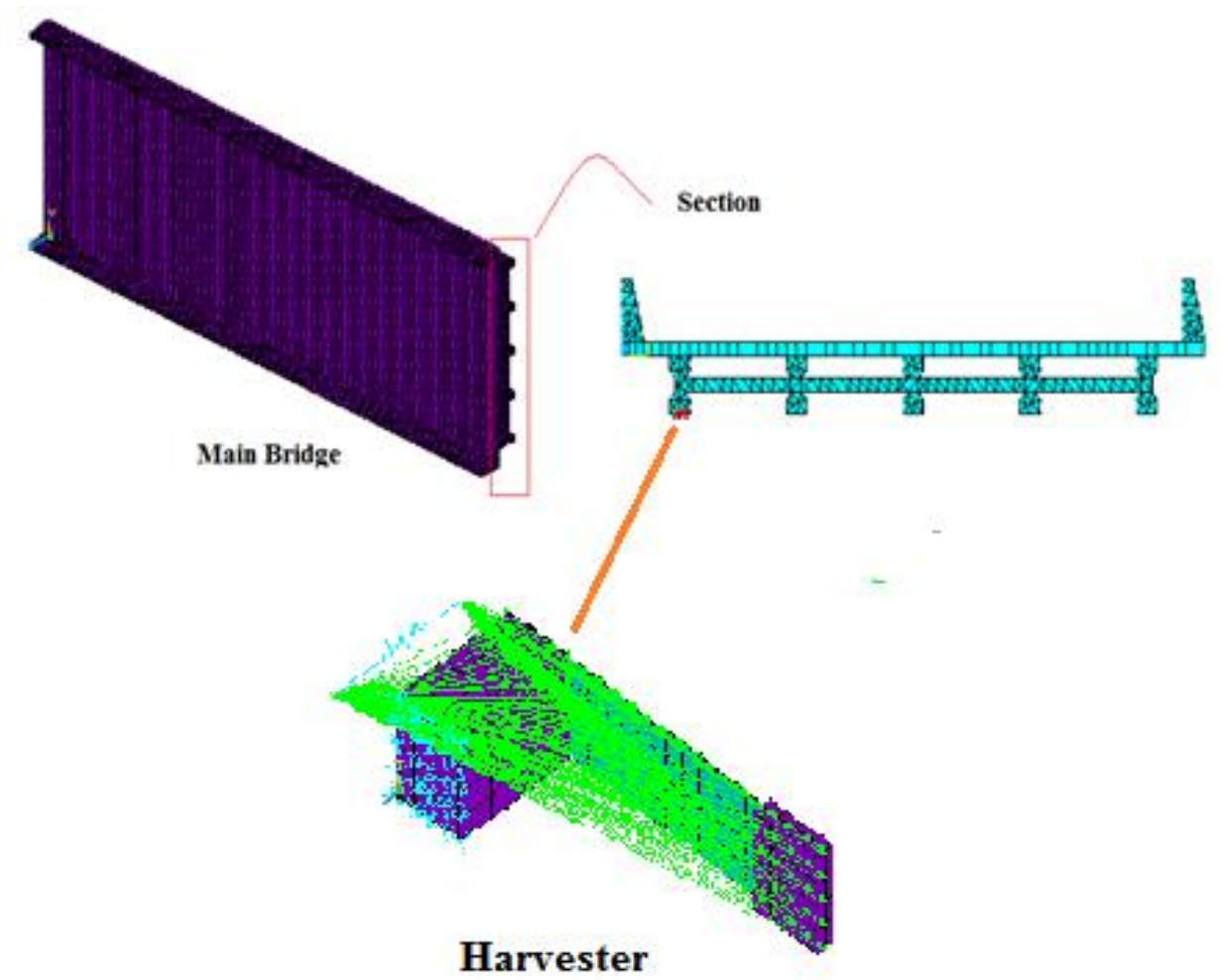

Figure 1. FEM model for the bridge with harvester

\section{Finite Element Modelling}

Piezoelectricity is defined as the ability to convert mechanical energy into electrical energy and vice versa. This phenomenon can be described mathematically as an interaction between the elastic and electric fields. The piezoelectric law is as follows (Tzou and Tseng, 1990).

$$
\left\{\begin{array}{l}
\{\sigma\}=[Q]\{\varepsilon\}-[e]^{T}\{E\} \\
\{D\}=[e]\{\varepsilon\}-[\epsilon]^{T}\{E\}
\end{array}\right\}
$$

where;

$\{\sigma\}:$ Stress

$\{\varepsilon\}$ : Strain

$\{$ D $\}$ : Electrical Displacement

$\{$ E\}: Electric Field Vectors

[Q]: Constitutive Matrix

[e]: Piezoelectric Stress Coefficient Matrix

$[\epsilon]$ : Dielectric Constants Matrix

Using the finite element method formulation coupled with Hamilton's principle and the previous mentioned piezoelectric constitutive equation, the harvester governing equation of motion was obtained as:

$$
\left\{\begin{array}{l}
{\left[M_{h}\right] \Pi^{u}+\left[C_{h}\right] \Pi^{l}+\left[K_{h}\right] \Pi-\left\{K_{m e}\right\} u_{p}=\left\{F_{m}\right\}} \\
\left\{K_{e}\right\} u_{p}{ }^{l}+\left[K_{m e}\right] \Pi^{l}+\frac{u_{p}}{R}=0
\end{array}\right\}
$$

where;

$\left[\mathrm{M}_{\mathrm{h}}\right]$ : Mass

$\left[\mathrm{C}_{\mathrm{h}}\right]$ : Damping

$\left[\mathrm{K}_{\mathrm{h}}\right]$ : Elastic Stiffness

$\left[\mathrm{K}_{\mathrm{me}}\right]$ : Piezoelectric

$\left[\mathrm{K}_{\mathrm{e}}\right]$ : Dielectric Stiffness Matrices

$\left\{F_{m}\right\}$ : Vector of External Nodal Mechanical Forces of the Harvester

Also $\Pi$ is nodal displacement vector, $\mathrm{R}$ is the resistance and $u_{p}$ is the voltage output. 


\section{ANSYS Modelling}

As mentioned previously, the model involved a bridge equipped with unimorph piezoelectric harvesters located at the bottom. The model was subjected to vehicle traffic that was simulated as a moving load traveling along the bridge. The harvester was designed as a cantilever beam with a fully covered piezoelectric layer and a tip mass at its free end. A resistor was attached to the piezoelectric in order to measure the electric load. The finite element (FE) modeling was carried out using ANSYS APDL. ANSYS offers two methods to design a structure: the first of these, picking from the graphical user interface menu and the other one, using APDL programming. APDL programming offers much better flexibility in terms of design parameters and analysis. It allows errors to be corrected by simply changing the code without repeating the whole task and gives the opportunity to control the analysis using implemented macros. Thus, in this study ANSYS APDL was used for the design and analysis task. Regarding the modeling, the structure was created through blocks using the block command in ANSYS. The blocks were divided into sub-sections using Volume devision command (VSBW) for practical meshing. Two types of elements were proposed to mesh the model. For the bridge, the harvester's substrate and the top mass SOLID45 were used, while for the piezoelectric material SOLID5 was used. To model the load, a resistance was connected to the piezoelectric harvesters and represented by the CIRCU94 element. The first end of the resistance was connected to the upper electrode and the second end was connected to the grounded electrode of the harvester. The proposed ANSYS model was also presented in Figure 1.

\section{RESULTS AND DISCUSSION}

The developed ANSYS model was subjected to a different type of analysis to quantify the harvested voltage. Eight piezoelectric harvesters of PZT type were installed symmetrically on the beams of the bottom of the bridge Figure 2 (a-b). Each harvester was connected to a resistor. The parameters for the bridge in used in the study of (Zhang et al., 2017) are given as:

Young Modulus $(\mathrm{E})=2.87 \mathrm{GPa}$

Length $=25 \mathrm{~m}$.

Width $=8 \mathrm{~m}$,

Thickness $=1.6 \mathrm{~m}$,

Density $(\rho)=2303 \mathrm{~kg} / \mathrm{m} 3$

In Table 1 are given geometrical, material and electromechanical parameters of the harvester.

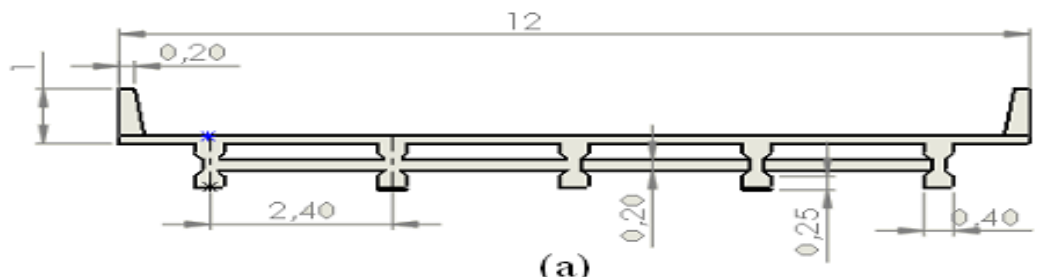

(a)

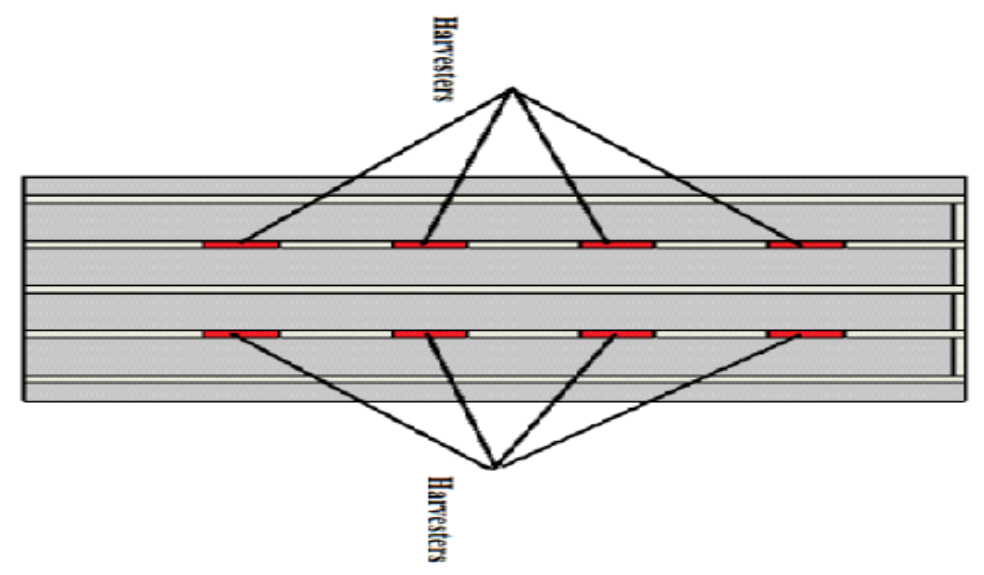

(b)

Figure 2. a) Bridge cross section b) Bottom view of the bridge with the harvesters 
Table 1. Geometrical, material and electromechanical parameters of the harvester (Junior et al. 2009)

\begin{tabular}{|c|c|}
\hline Parameters & Value \\
\hline Length of the harvester (m) & 0.1 \\
\hline Width of the harvester (m) & 0.02 \\
\hline Thickness of the harvester (m) & 0.0004 \\
\hline Thickness of the substrate (m) & 0.0005 \\
\hline Young's modulus of the substrate (GPa) & 100 \\
\hline$C_{11}^{\text {piezo }}, C_{22}^{\text {piezo }}(\mathrm{GPa})$ & 120.3 \\
\hline$C_{12}^{\text {piezo }}(\mathrm{GPa})$ & 75.2 \\
\hline$C_{13}^{\text {piezo }}, C_{23}^{\text {piezo }}(\mathrm{GPa})$ & 75.1 \\
\hline$C_{33}^{\text {piezo }}(\mathrm{GPa})$ & 110.9 \\
\hline$C_{66}^{\text {piezo }}(\mathrm{GPa})$ & 22.7 \\
\hline Mass density of the PZT $\left(\mathrm{kg} / \mathrm{m}^{3}\right)$ & 7800 \\
\hline Mass density of the substrate $\left(\mathrm{kg} / \mathrm{m}^{3}\right)$ & 7165 \\
\hline Piezoelectric constant $e_{31}, e_{32}\left(\mathrm{C} / \mathrm{m}^{2}\right)$ & -5.2 \\
\hline Piezoelectric constant $e_{33}\left(\mathrm{C} / \mathrm{m}^{2}\right)$ & 15.9 \\
\hline Permittivity $\in_{33}(\mathrm{nF} / \mathrm{m})$ & 15 \\
\hline Resistive load, R $(\Omega)$ & $1 \mathrm{e} 8$ \\
\hline$\alpha(\mathrm{rad} / \mathrm{s})$ & 4.886 \\
\hline$\beta(\mathrm{s} / \mathrm{rad})$ & $1.2433 \times 10^{-5}$ \\
\hline
\end{tabular}

To study the behavior of the bridge and harvesters and to determine their resonant frequencies, a modal analysis in ANSYS APDL was used. Table 2 presents the four first frequencies of the bridges and the harvesters. The corresponding mode shapes of the bridge are depicted in Figure 3.

Table 2. Natural frequencies of the bridge and the harvester

\begin{tabular}{lcl}
\hline & Harvester & Bridge \\
\cline { 2 - 3 } Mode 1 & 6.7081 & 1.7125 \\
Mode 2 & 68.009 & 5.2888 \\
Mode 3 & 68.009 & 6.5050 \\
Mode 4 & 87.381 & 9.4384 \\
\hline
\end{tabular}




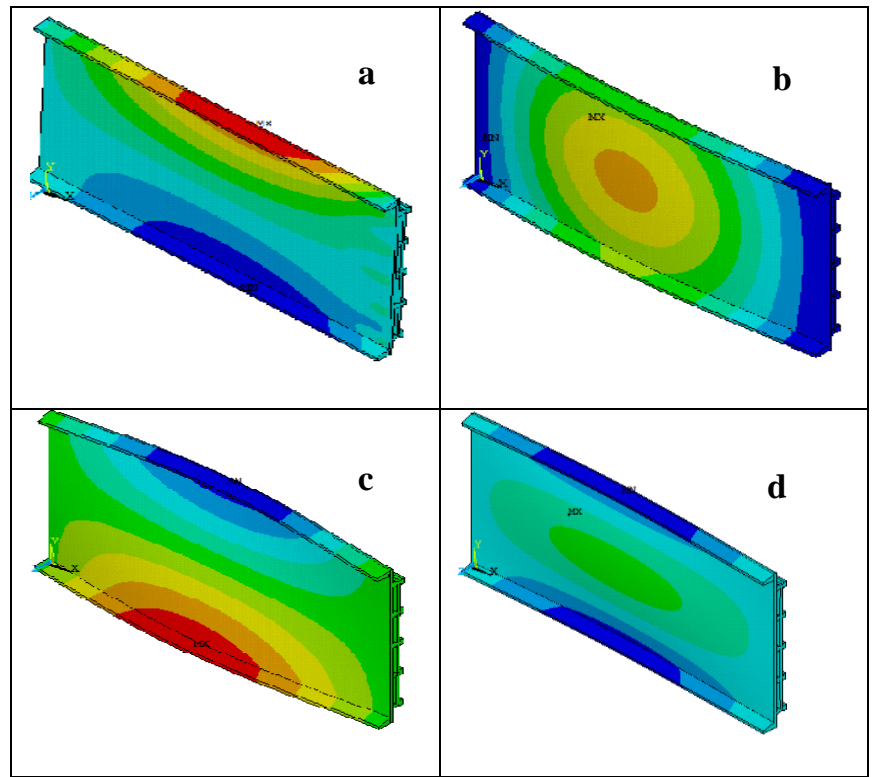

Figure 3. Mode shapes of the bridge

A numerical analysis was conducted to determine the effect of the positions of the harvesters and the load frequency on the harvested voltage. Figure 4 shows the variation of the harvested voltage against the excitation frequency. It can be noticed from the figure that the harvesters generated maximum peak voltage across the resistors at the resonance frequency. It was also observed that the voltage amplitude increase when the harvester was placed at the maximum mode shape amplitude.

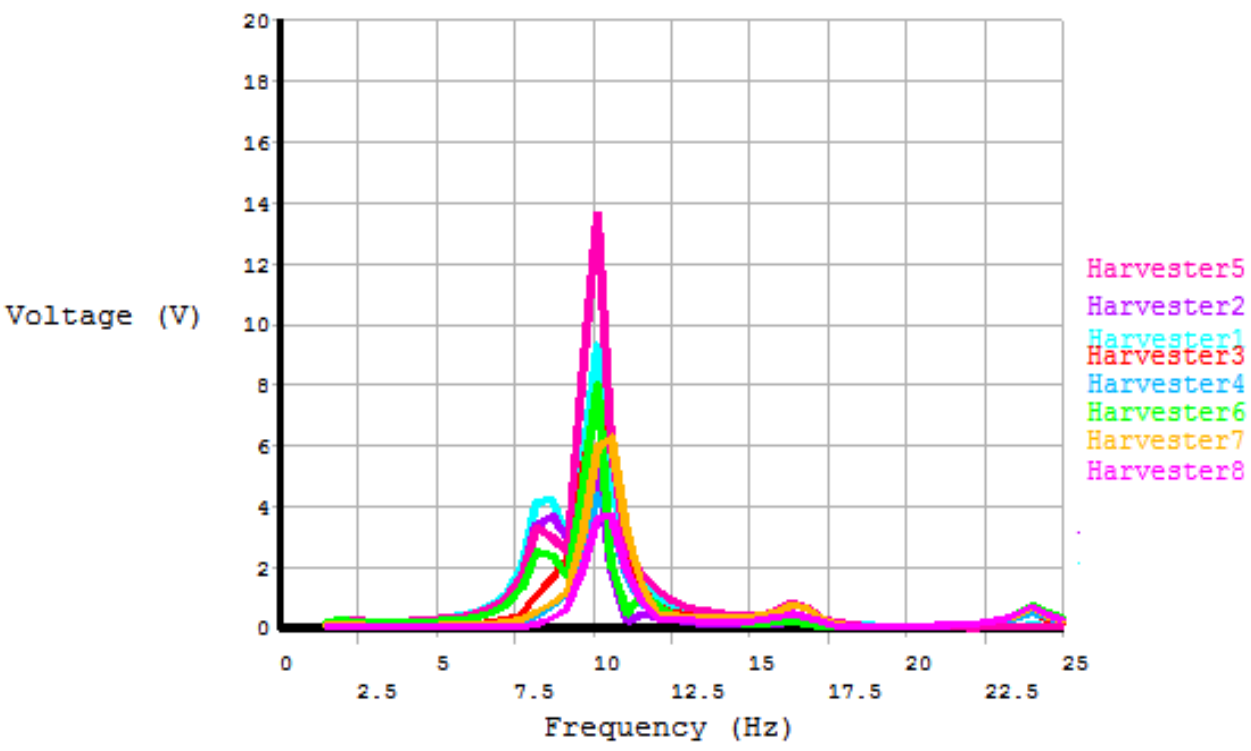

Figure 4. Voltage frequency response functions for the harvesters 
The effect of the moving load on the harvested voltage was investigated. In the first analysis, a single load was supposed to be moved across the bridge. The load was a sinus function with an amplitude equal to $50 \mathrm{KN}$ and had a frequency equal to the fourth natural frequency of the bridge. As it can be observed from Figure 5, a maximum voltage of $0.8 \mathrm{~V}$ was generated by the third harvester. This was expected as the supreme amplitude of the third mode shape of the bridge was located in that area.

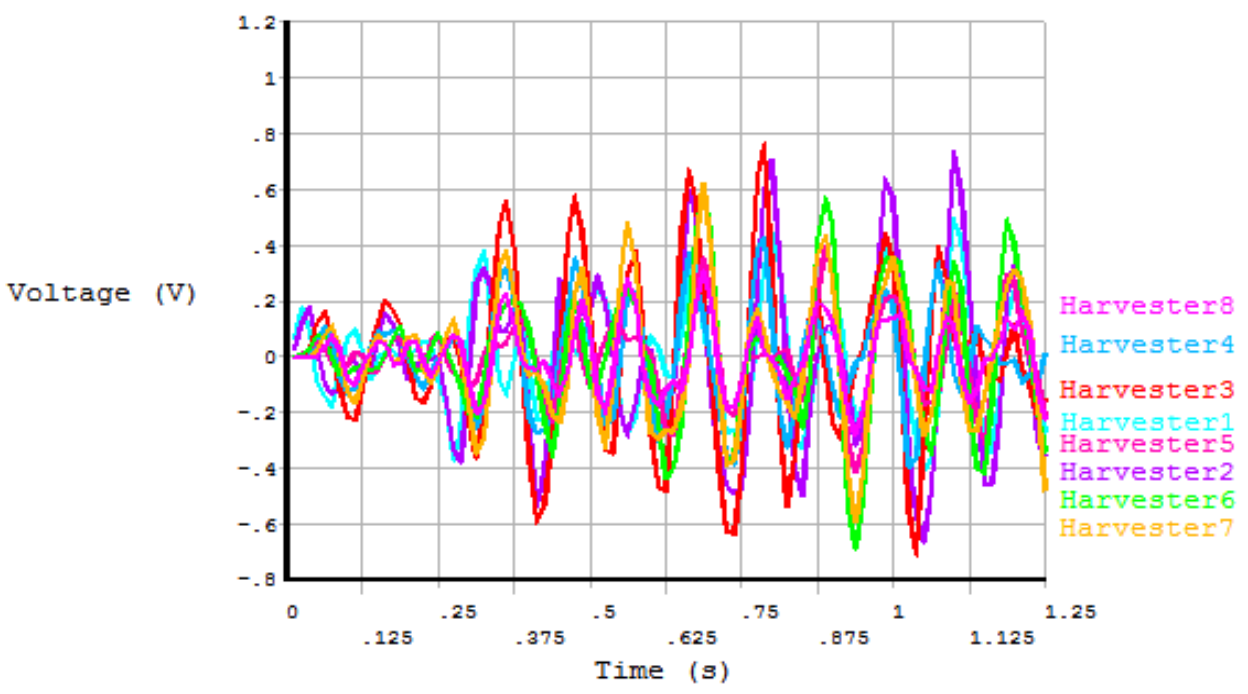

Figure 5. Voltage output of the harvesters under single moving load

The next analysis was conducted with two moving loads with the same amplitude and frequency as the previous analysis. The loads were made to travel across the bridge in reverse directions with a velocity equal to $20 \mathrm{~m} / \mathrm{s}$. It can be seen from Figure 6 that the values of the voltage harvesting were higher than those obtained with the single load, which was determined to be normal as the acceleration of the bridge was bigger. The maximum voltages were extracted from harvester number three and number six. This was due to the fact that the load frequency corresponding mode shape had a symmetric behavior Figure 3 and it was maximum at the position of harvester number three and number six.

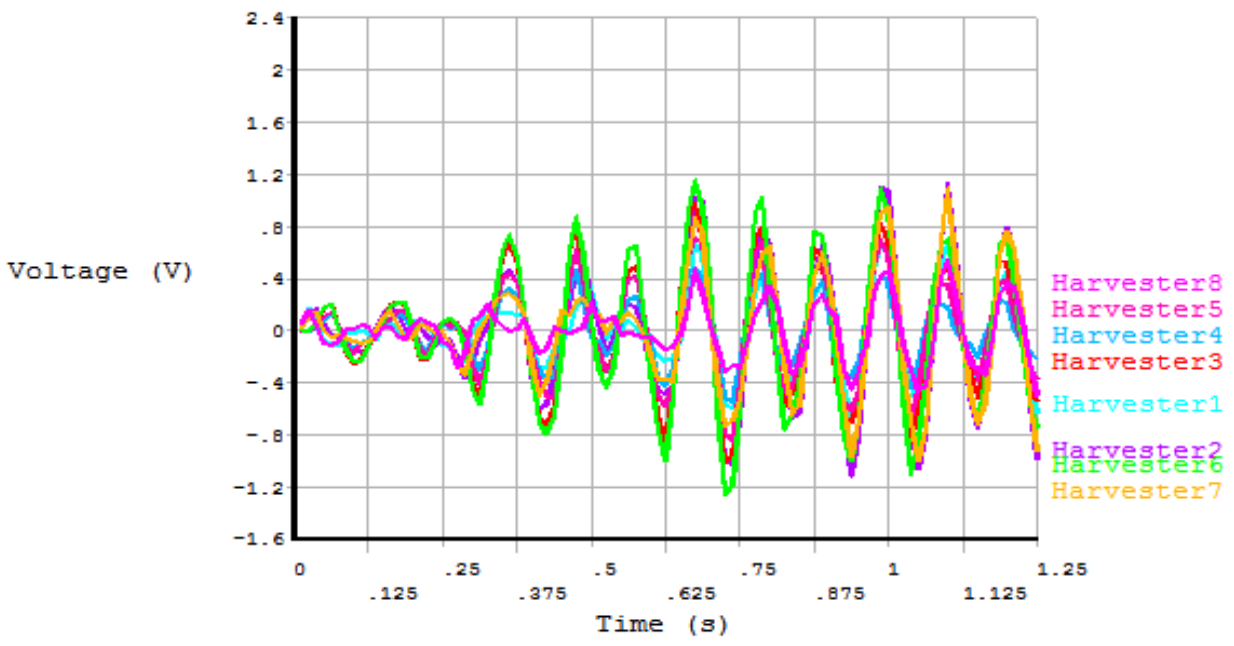

Figure 6. Voltage output of the harvesters under double moving loads 
In real life, the vibration of bridges is induced by different kinds of vehicles with diverse masses. In the following simulation double sinus moving [20e3,140e3]. The full APDL code used to generate the random moving loads is given in the Appendix. The time history output voltage is given in Figure 7. As can be seen from the figure, the maximum voltage was recorded on harvester number six, for loads with random amplitudes were used. The loads traveled across the bridge in opposite directions and were taken to be a PRBS signal with an interval of the same reason as in the previous analysis. Moreover, in this analysis, the harvester voltage reached $2 \mathrm{~V}$, which was $80 \%$ higher than in the previous analysis. Due to the change in amplitude which led to a larger force.

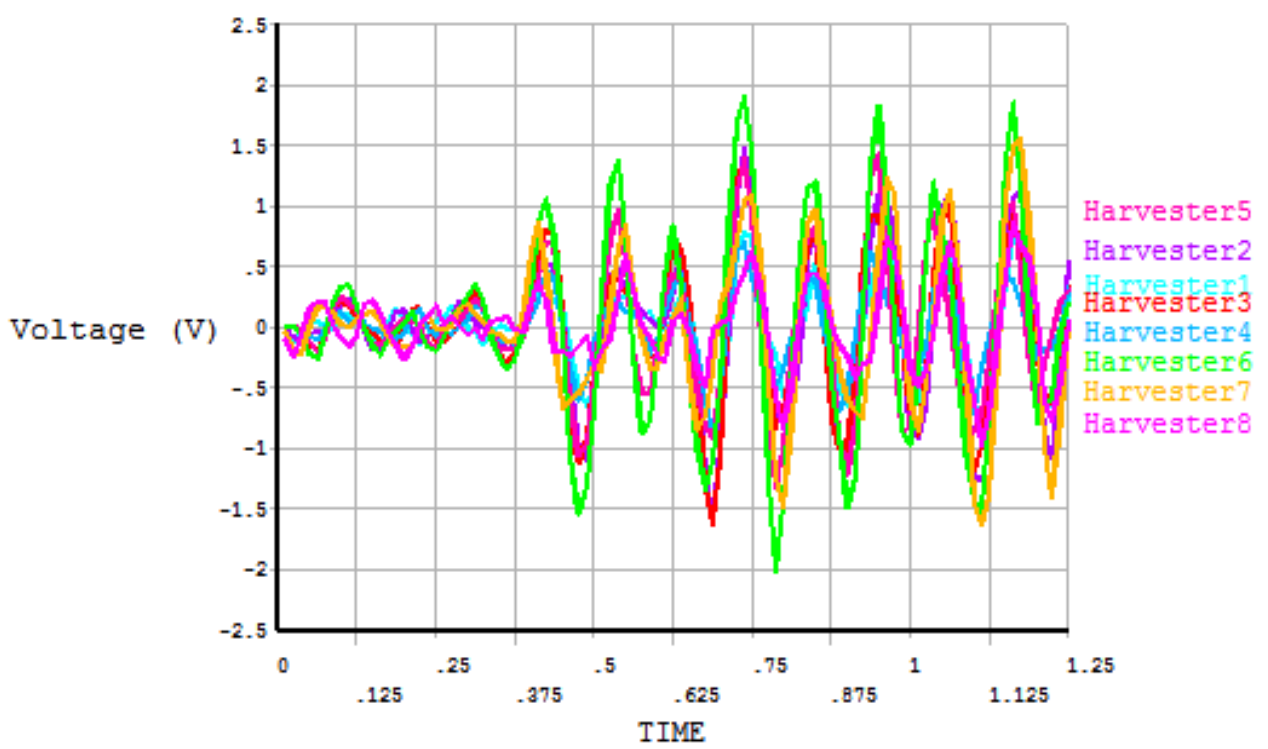

Figure 7. Voltage output of the harvesters under double moving loads with random amplitudes

\section{CONCLUSION AND SUGGESTIONS}

The vibration that occurs on bridges as a result of moving vehicles is an unlimited source of energy that can be converted into a useful electric power using a piezoelectric mechanism. In this study, a new numerical model of a real-life bridge with piezoelectric harvesters was modeled using ANSYS APDL. Different numerical simulations were performed of the bridge under a single moving force and multiple moving forces. The numerical simulations demonstrated the following:

- The maximum voltage was obtained when the load frequency was closed to the resonance frequency of the bridge or the harvesters,

- The best location for the harvesters was in the area of the maximum mode shape amplitude,

- The harvesting voltage was proportional to the number and the amplitude of the moving forces.

However, to ensure a better performance of the harvesters, optimization of their locations and sizes are required, which can an area to be investigated in future research.

\section{CONFLICT OF INTEREST STATEMENT}

The author declares that there is no conflict of interest in this study.

\section{RESEARCH AND PUBLICATION ETHICS STATEMENT}

The author declares that the research and publication ethics are complied with in the study.

\section{REFERENCES}

Anton, S.R., Sodano, H.A., 2007. A review of power harvesting using piezoelectric materials (2003-2006). Smart Materials and Structures, 16(3):1-10.

Basset, P., Galayko, D., Cottone, F., Guillemet, R., Blokhina, E., Marty, F., Bourouina, T., 2014. Electrostatic vibration energy harvester with combined effect of electrical nonlinearities and mechanical impact. Journal of Micromechanics and Microengineering, 24(3):1-10. 
Bendine, K., Boukhoulda, F.B., Haddag, B., Nouari, M., 2017. Active vibration control of composite plate with optimal placement of piezoelectric patches. Mechanics of Advanced Materials and Structures, 26(4):341-349.

Bendine, K., Hamdaoui, M., Boukhoulda, B.F., 2019. Piezoelectric energy harvesting from a bridge subjected to time-dependent moving loads using finite elements. Arabian Journal for Science and Engineering, 44:5743-5763.

Boisseau, S., Despesse, G., Seddik, B.A., 2012. Electrostatic conversion for vibration energy harvesting. Small-Scale Energy Harvesting, pp. 91 134.

Cahill, P., Nuallain, N.A.N., Jackson, N., Mathewson, A., Karoumi, R., Pakrashi, V., 2014. Energy harvesting from train-induced response in bridges. Journal of Bridge Engineering, 19(9): 04014034.

Erturk, A., Inman, D.J., 2008. A distributed parameter electromechanical model for cantilevered piezoelectric energy harvesters. Journal of Vibration and Acoustics, 130(4): 041002.

Erturk, A., Renno, J.M., Inman, D.J., 2009. Modeling of piezoelectric energy harvesting from an L-shaped beam-mass structure with an application to UAVs. Journal of Intelligent Material Systems and Structures, 20(5):529-544.

Erturk, A., 2011. Piezoelectric energy harvesting for civil infrastructure system applications: Moving loads and surface strain fluctuations. Journal of Intelligent Material Systems and Structures, 22(17):1959-1973.

Jung, I., Shin, Y.-H., Kim, S., Choi, J., Kang, C.-Y., 2017. Flexible piezoelectric polymer-based energy harvesting system for roadway applications. Applied Energy, 197:222-229.

Junior, C.D.M., Erturk, A., Inman, D.J., 2009. An electromechanical finite element model for piezoelectric energy harvester plates. Journal of Sound and Vibration, 327:9-25.

Karimi, M., Karimi, A.H., Tikani, R., Ziaei-Rad, S., 2016. Experimental and theoretical investigations on piezoelectric-based energy harvesting from bridge vibrations under travelling vehicles. International Journal of Mechanical Sciences, 119:1-11.

Kim, S., Pakzad, S., Culler, D., Demmel, J., Fenves, G., Glaser, S., Turon, M., 2007. Health monitoring of civil infrastructures using wireless sensor networks. Proceedings of the 6th International Conference on Information Processing in Sensor Networks, ACM, 254-263.

Lin, Z.-Q., Gea, H.C., Liu, S.-T., 2011. Design of piezoelectric energy harvesting devices subjected to broadband random vibrations by applying topology optimization. Acta Mechanica Sinica, 27(5):730-737.
Lynch, J.P., Loh, K.J., 2006. A summary review of wireless sensors and sensor networks for structural health monitoring. Acta Mechanica Sinica, 38:91-130.

Paek, J., Chintalapudi, K., Govindan, R., Caffrey, J., Masri, S., 2005. A wireless sensor network for structural health monitoring: Performance and experience. Performance and Experience, in: Emnets. IEEE,1-9.

Park, H., Kim, J., 2016. Design of piezoelectric energy harvesting devices subjected to broadband random vibrations by applying topology optimization. International Journal of Precision Engineering and Manufacturing-Green Technology, 3(1):41-48.

Peigney, M., Siegert, D., 2013. Piezoelectric energy harvesting from traffic-induced bridge vibrations. Smart Materials Structure, 22:95019.

Song, Y., 2018. Finite-element 1mplementation of piezoelectric energy harvesting system from vibrations of railway bridge. Journal of Energy Engineering, 145(2): 04018076.

Torres, E., Ponce, P., Molina, A., 2017. Electromagnetic induction generator toward energy harvesting for dynamic systems. Industrial Technology (ICIT), 2017 IEEE International Conference on. IEEE, 418-422.

Tzou, H.S., Tseng, C.I., 1990. Distributed piezoelectric sensor/actuator design for dynamic measurement/control of distributed parameter systems: a piezoelectric finite element approach. Journal of Sound and Vibration, 138:17-34.

Upadrashta, D., Yang, Y., 2015. Finite element modeling of nonlinear piezoelectric energy harvesters with magnetic interaction. Smart Materials Structure, 24:45042.

Zhang, Y., Cai, S.C., Deng, L., 2014. Piezoelectric-based energy harvesting in bridge systems. Journal of Intelligent Material Systems and Structures, 25: 1414-1428.

Zhang, Z., Xiang, H., Shi, Z., 2016. Modeling on piezoelectric energy harvesting from pavements under traffic loads. Journal of Intelligent Material Systems and Structures, 27: 567-578.

Zhang, Z., Xiang, H., Shi, Z., 2017. Mechanism exploration of piezoelectric energy harvesting from vibration in beams subjected to moving harmonic loads. Composite Structures, 179: 368-376.

Zhang, Z., Xiang, H., Shi, Z., Zhan, J., 2018. Experimental investigation on piezoelectric energy harvesting from vehicle-bridge coupling vibration. Energy Conversion and Management, 163: 169-179.

Zhao, Q., Liu, Y., Wang, L., Yang, H., Cao, D., 2018. Design method for piezoelectric cantilever beam structure under low frequency condition. International Journal of Pavement Research and Technology, 11(2): 153-159. 
Appendix 1.

APDL Macro File for Random Moving Loads

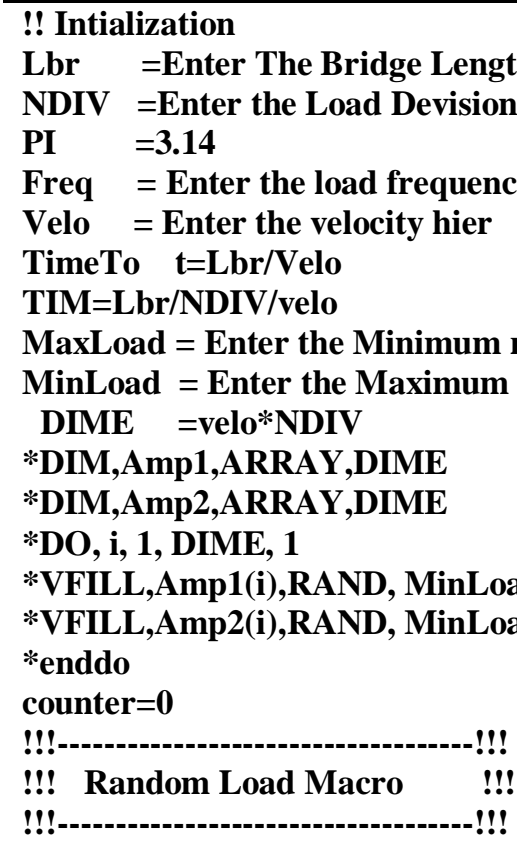

*CREATE,FORCE

FDELE,ALL

*do,i,1,DIM,1

DDELE,Up(i),VOLT !DELETE VOLTAGE ON SENSORS ELECTRODE

*enddo

TIME,ARG1

Force $=\operatorname{node}($ ARG2,Wbr/4,Hbr)

Force $2=$ node $(\mathrm{ARG3}, 3 * \mathrm{Wbr} / \mathbf{4}, \mathrm{Hbr})$

amplitude1 $=$ ARG4 $* \sin ($ Freq $* 2 *$ PI*ARG1)

amplitude $2=$ ARG $5 * \sin ($ Freq $* 2 *$ PI $*$ ARG1 $)$

F,Force,FZ,amplitude1

F,Force2,FZ,amplitude2

solve

*END

!!! End Macro !!!

!!!-------------------------!!!

!! Transient Analysis

/SOLU

ANTYPE, 4

TRNOPT,FULL,,DAMP

LUMPM,0

OUTRES,ALL,ALL

DELTIM,0.1*TIM,0.01*TIM,TIM,ON

!DELTIM,TIM ! Specifies the time step sizes

TINTP,,0.25,0.5,0.5

KBC,1

! Ramped load step

*DO,K,TIM,TimeTot,TIM

counter=counter+1

*USE,FORCE,K,K*velo,(TimeTot-K)*velo,Amp1(counter),Amp2(counter)

*ENDDO 